\title{
EFFECT OF SOMATOTROPIN AND THYROXINE ON THE IN VITRO DEVELOPMENT OF BOVINE PREANTRAL FOLLICLES
}

\section{EFEITO DA SOMATOTROPINA E TIROXINA NO DESENVOLVIMENTO IN VITRO DE FOLÍCULOS PRÉ-ANTRAIS BOVINOS}

\author{
Talita Fernandes da Silva ${ }^{1}$ \\ Sanely Lourenço da Costa ${ }^{1^{*}}$ \\ Eduardo Paulino da Costa ${ }^{1}$ \\ José Domingos Guimarães ${ }^{1}$ \\ ${ }^{1}$ Universidade Federal de Viçosa. Voçosa, MG, Brazil. \\ *Author for correspondence - sanelylc@hotmail.com
}

\begin{abstract}
The aim of the study was to evaluate the effect of recombinant bovine somatotropin (rbST) and thyroxine $\left(\mathrm{T}_{4}\right)$ on survival and growth of bovine preantral ovarian follicles (PAOF) cultured in vitro. Ovarian fragments were collected in local abattoirs and immediately fixed for classical histology and transmission electron microscopy (non-cultured control). The other fragments were then cultured in situ for seven days in minimum essential medium alone $\left(\mathrm{MEM}^{+}\right.$- cultured control) or in the presence of $1,000 \mathrm{ng} / \mathrm{mL} \mathrm{rbST}$ and $20 \mathrm{ng} / \mathrm{mL} \mathrm{T}_{4}$, isolated or associated. After seven days, there was a reduction $(\mathrm{P}<0.05)$ in the percentage of normal follicles in $\mathrm{MEM}^{+}$alone or with $\mathrm{T}_{4}$. In oocyte diameter, there was a reduction in $\mathrm{MEM}^{+}$alone. There was no influence $(\mathrm{P}>0.01)$ of the medium used on the follicular diameter of the PAOF cultured for seven days. Ultrastructural analysis showed cell damage. In conclusion, the presence of rbST maintains the rate of morphologically normal follicles during the culture for seven days (observed by optical microscopy), but it does not exert beneficial effects on its ultrastructural integrity and oocyte and follicular growth.
\end{abstract}

Keywords: bovine; hormones; in vitro culture; ovarian follicles.

\section{Resumo}

O objetivo do trabalho foi avaliar o efeito da somatotropina recombinante bovina (rbST) e da tiroxina $\left(\mathrm{T}_{4}\right)$ sobre a sobrevivência e o crescimento de folículos ovarianos pré-antrais (FOPA) bovinos cultivados in vitro. Fragmentos ovarianos foram coletados em abatedouros locais e imediatamente fixados para histologia clássica e microscopia eletrônica de transmissão (controle não cultivado). Os demais fragmentos foram cultivados in situ por sete dias em meio essencial mínimo sozinho (MEM ${ }^{+}$ - controle cultivado), ou na presença de $1.000 \mathrm{ng} / \mathrm{mL}$ de $\mathrm{rbST}$ e $20 \mathrm{ng} / \mathrm{mL}$ de $\mathrm{T}_{4}$, isoladamente ou em associação. Após sete dias, houve redução $(\mathrm{P}<0,05)$ na percentagem de folículos normais no $\mathrm{MEM}^{+}$ sozinho ou quando adicionado $\mathrm{T}_{4}$. No diâmetro oocitário, houve redução no $\mathrm{MEM}^{+}$sozinho. Não houve influência $(\mathrm{P}>0,01)$ do meio utilizado, no diâmetro folicular, dos FOPA cultivados por sete dias. A análise ultraestrutural demonstrou danos celulares. Conclui-se que, apesar da presença da rbST manter a taxa de folículos morfologicamente normais durante o cultivo por sete dias (observado por microscopia óptica), o uso de $\mathrm{rbST}_{\mathrm{e}} \mathrm{T}_{4} \mathrm{em}$ meio de cultivo in vitro de FOPA, nas concentrações utilizadas no presente experimento, não exerce efeitos benéficos quanto à integridade ultraestrutural 
e aos crescimentos oocitário e folicular.

Palavras-chave: bovinos; cultivo in vitro; folículos ovarianos; hormônios.

Received on: March 21 ${ }^{\text {th }}, 2017$.

Accepted on: March 5 $5^{\text {th }}, 2018$.

\section{Introduction}

Preantral ovarian follicles (PAOF) comprise about $90 \%$ of all follicular population present in the mammalian ovary ${ }^{(1)}$. However, in the physiological process occurring in vivo, more than $99 \%$ of them undergo atresia ${ }^{(2)}$. Thus, the increase in the reproductive potential of mammalian females is related to the maximum use of these ovarian follicles, enabled by the application of biotechniques. In this context, the manipulation of oocytes enclosed in preantral ovarian follicles stands out ${ }^{(3)}$.

The follicular development process is dependent on hormones and growth factors that act mainly in oocytes and granulosa cells (GC), promoting its development ${ }^{(4)}$. Therefore, studies that aim to obtain a culture system that allows the maintenance of the viability of these follicles and their posterior development are necessary.

In cattle, the first studies related to in vitro culture of PAOF occurred in the decade of $1990^{(5)}$, and the best result reported for this species so far was the formation of the antral cavity ${ }^{(6)}$. However, an adequate culture system able to promote the complete development of PAOF in domestic animals has not been developed yet ${ }^{(7)}$.

Among the hormones currently studied in animal reproduction is somatotropin (ST). This hormone exerts influence in the mechanisms related to follicular growth and maturation, as well as in the regulation of physiological processes of the animals ${ }^{(8)}$, acting through the synthesis of insulin-like growth factor 1 (IGF-1) and IGF binding proteins (IGFBP) ${ }^{(9)}$.

Another hormone that has been a target of research in this area is thyroxine, synthesized by the thyroid gland. Arunakumari et al. ${ }^{(10)}$ reported the influence of this hormone in combination with FSH in the in vitro development of PAOF of goats, in which they verified meiotically competent oocytes. Despite its known influence in ovarian folliculogenesis ${ }^{(11)}$, its effect on the development of PAOF of domestic animals is still little elucidated.

Thus, by observing rbST and $\mathrm{T}_{4}$ potential, this study aimed to evaluate the effect of these hormones, isolated or in the association, on the survival and growth of bovine PAOF cultured in situ.

\section{Material and Methods}

This research was approved by the Ethics Committee on the Use of Animals of the Federal University of Viçosa (CEUA/UFV, process number 08/2013). Pairs of ovaries $(n=5)$ from bovine females were collected at local abattoirs. Immediately after collection, they were washed in alcohol $70 \%$ and then in minimum essential medium (MEM), supplemented with $100 \mu \mathrm{g} / \mathrm{mL}$ penicillin and $100 \mu \mathrm{g} / \mathrm{mL}$ streptomycin. Subsequently, they were transported to the animal reproduction laboratory (DVT/UFV) in MEM at $4{ }^{\circ} \mathrm{C}$ for approximately one hour, according to Chaves ${ }^{(12)}$. 
In the laboratory, they were placed in a Petri dish containing MEM with HEPES, on which fragments of approximately $3 \times 3 \mathrm{~mm}$ ( $1 \mathrm{~mm}$ thick) were obtained using tweezers and scalpel blades under sterile conditions. A fragment from each ovary pair was randomly selected and immediately fixed for analysis by classical histology $(\mathrm{CH})$ and transmission electron microscopy (TEM), constituting the non-cultured control. The other fragments were individually cultured in $1 \mathrm{~mL}$ medium for seven days, in a culture dish at $38{ }^{\circ} \mathrm{C}$ and $5 \% \mathrm{CO}_{2}$. It is worth mentioning that each ovarian pair corresponded to a repetition and, therefore, five repetitions were performed.

The base medium, called MEM (pH 7.2-7.4), was supplemented with ITS (10 $\mu \mathrm{g} / \mathrm{mL}$ insulin, 5.5 $\mu \mathrm{g} / \mathrm{mL}$ transferrin, and $5 \mathrm{ng} / \mathrm{mL}$ selenium), $2 \mathrm{mM}$ glutamine, $2 \mathrm{mM}$ hypoxanthine, and $1.25 \mathrm{mg} / \mathrm{mL}$ bovine serum albumin (BSA). The culture performed only with the base medium supplemented was called cultured control $\left(\alpha-\mathrm{MEM}^{+}\right)$, and the other treatments consisted of the culture with $\alpha-\mathrm{MEM}^{+}$ added of $1000 \mathrm{ng} / \mathrm{mL}$ recombinant bovine somatotropin ( $\mathrm{rbST}$ ) or $20 \mathrm{ng} / \mathrm{mL}$ thyroxine $\left(\mathrm{T}_{4}\right.$ ), or added of both hormones (1,000 and $20 \mathrm{ng} / \mathrm{mL}$, respectively). These concentrations were used after previous studies performed by our team when added to in vitro culture of PAOF of cattle ${ }^{(13)}$ and goats ${ }^{(14)}$. The culture media were stabilized for one hour before use, being completely renewed every two days.

After seven days of culture, the fragments were fixed in Carnoy for four hours and directed to $\mathrm{CH}$. Primarily, they were dehydrated at increasing concentrations of ethanol, being then diaphonized in xylol. The fragments were then embedded in paraffin blocks and serially sectioned to the thickness of $7 \mu \mathrm{m}$. Each section was placed on a slide and stained by the Periodic acid-Schiff technique and hematoxylin. All sections were examined under an optical microscope (Olympus), at 400x magnification. For each treatment, 30 follicles were counted, random without choice, degenerate or normal.

In relation to follicular survival, the follicles were classified as normal or degenerated. PAOFs present in the ovarian tissue were considered morphologically normal when they presented granulosa cells (GC) organized around the oocyte, whereas it was spherical or slightly elongated, with nucleus without evidence of pyknosis ${ }^{(15)}$. Degenerated follicles were characterized according to GC disorganization around the oocyte and to the presence of areas of cytoplasmic retraction and/or nuclear pyknosis ${ }^{(16)}$.

Oocyte and follicular diameters were measured with the aid of an ocular micrometer, and the measurement was performed on follicles classified as normal in the histological analysis.

Procedures for transmission electron microscopy (TEM) were performed according to Costa ${ }^{(17)}$. Small fragments $\left(1 \mathrm{~mm}^{3}\right)$ of ovarian tissues were fixed for four hours at room temperature in Karnovsky (2.5\% glutaraldehyde and $4 \%$ formaldehyde in $0.1 \mathrm{M}$ cacodylate buffer, $\mathrm{pH} 7.2$ ). Afterward, the samples were washed twice in $0.1 \mathrm{M}$ cacodylate buffer, post-fixed in $1 \%$ osmium tetroxide, dehydrated in alcohol and embedded in Epon 812 resin $^{(18)}$.

Initially, semithin sections $(0.5 \mu \mathrm{m})$ were performed with glass knives in ultramicrotome. These were stained with toluidine blue, placed on a slide/coverslip and examined under a light microscope, selecting the best semithin sections for the ultrathin sections $(60-70 \mathrm{~nm})$. The ultrathin sections were obtained with a diamond knife and collected on (200 mesh) copper grids, stained with uranyl acetate and lead citrate, according to the protocols of Watson ${ }^{(19)}$ and Reynolds ${ }^{(20)}$. Subsequently, the ultrathin sections were examined by transmission electron microscopy as the integrity and density of the cytoplasmic organelles of the oocyte and GC, the degree of cytoplasmic vacuolization, and the integrity of cell membranes.

The variables were submitted to normality (Lilliefors) and homoscedasticity (Cochran) tests, 
followed by analysis of variance at a probability of 5\%. In case of significance, the most appropriate test of comparison between means was performed, avoiding type I and II statistical errors. When they did not satisfy the requirements of normality and homoscedasticity, even after the appropriate transformations (angular for percentages and radicial for diameters) data were submitted to KruskalWallis non-parametric test ${ }^{(21)}$.

\section{Results and Discussion}

Normal (Fig. 1: A and B) and degenerated (Fig. 1: C and D) follicles were observed in both groups (non-cultured and cultured). In morphologically normal follicles, the oocyte had a spherical or slightly elongated format, with organized GC nucleus without the presence of cytoplasmic retraction, as reported by Bruno et al. ${ }^{(15)}$. In contrast, degenerated follicles had retracted oocytes, with disorganized GC and the presence of nuclear pyknosis ${ }^{(16)}$.

After seven days of culture, there was a reduction $(\mathrm{P}<0.05)$ on the rate of normal follicles in fragments cultured in the absence of hormones $\left(\alpha-\mathrm{MEM}^{+}\right)$and in the medium containing $\mathrm{T}_{4}$, as shown in Table 1. This result shows that rbST was beneficial, once its presence in the medium maintained follicular viability during the culture for seven days.
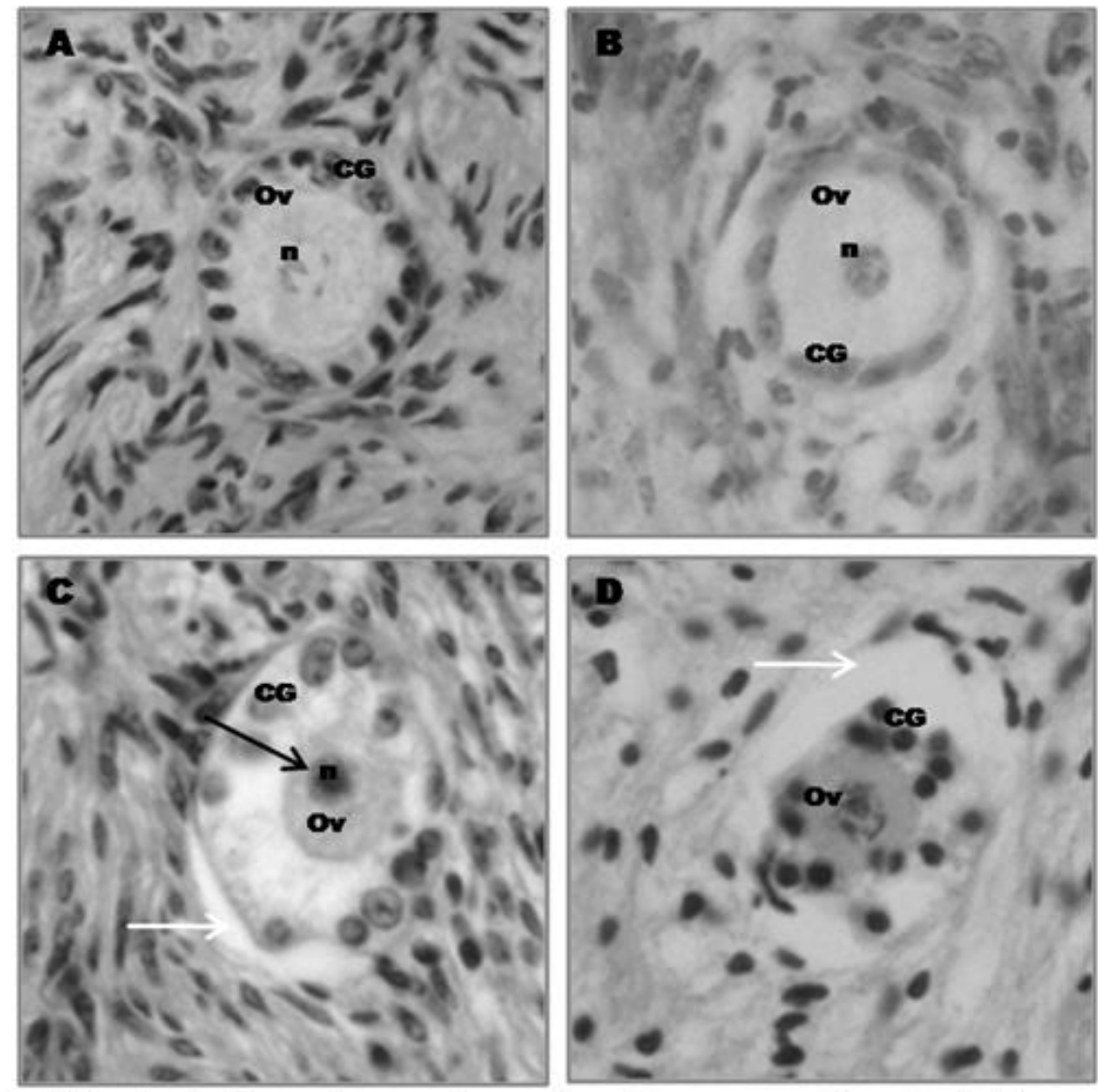

Figure 1. Histological sections of ovarian fragments after Periodic acid-SchiffHematoxylin staining, showing a normal follicle in non-cultured control fragment(A); fragment cultured for seven days with $1,000 \mathrm{ng} / \mathrm{mL} \mathrm{rbST}$ (B) and degenerated follicles (C and D). GC: granulosa cells; Ov: oocyte; n: oocyte nucleus. Black arrows: pyknotic nucleus. White arrows: oocyte with cytoplasmic retraction. $400 \mathrm{x}$ magnification. 
The composition of the culture medium used as a base is one of the major factors that affect follicular survival and development rates ${ }^{(22)}$. In the present study, the medium used was $\mathrm{MEM}^{+}$, and some supplements were added to this medium, such as insulin, transferrin, selenium and bovine serum albumin. Insulin allows a greater use of the medium energy sources ${ }^{(23)}$. Selenium has the function of activating enzymes that participate in the process of eliminating free radicals produced by cells ${ }^{(24)}$. However, these substances were not able to maintain follicular viability rate, when compared to that observed in normal PAOF of the non-cultured group.

These results evidence the importance of rbST in the culture medium since both media containing only rbST or an association of rbST with $\mathrm{T}_{4}$ maintained $(\mathrm{P}>0.05)$ follicular survival during in vitro culture for seven days.

Table 1. Percentage (average \pm standard deviation) of morphologically normal PAOF in non-cultured tissue and tissue cultured for seven days (concentration in $\mathrm{ng} / \mathrm{mL}$ )

\begin{tabular}{ll}
\hline Treatment & Day 7 (\%) \\
\hline Control & $85.3 \pm 5.0^{\mathrm{a}}$ \\
$\alpha-\mathrm{MEM}^{+}$ & $80.0 \pm 2.4^{\mathrm{b}}$ \\
$\alpha-\mathrm{MEM}^{+}+\operatorname{rbST}(1,000)$ & $86.0 \pm 4.4^{\mathrm{a}}$ \\
$\alpha-\mathrm{MEM}^{+}+\mathrm{T}_{4}(20)$ & $75.3 \pm 5.0^{\mathrm{b}}$ \\
$\alpha-\mathrm{MEM}^{+}+\operatorname{rbST}(1,000)+\mathrm{T}_{4}(20)$ & $85.3 \pm 8.1^{\mathrm{a}}$ \\
\hline
\end{tabular}

Percentages with different superscript letters show a significant difference $(\mathrm{P}<0.05)$ by Scott-Knott test.

For each treatment, 30 follicles were counted.

It is known that the major rbST action mechanism on folliculogenesis occurs by the induction of increased plasma and ovarian concentrations of IGF-1 ${ }^{(25)}$. This growth factor, in turn, is capable of suppressing DNA fragmentation by apoptosis, acting as an anti-apoptotic factor ${ }^{(26)}$. In cattle, some studies showed that GH acts through IGF- $\mathrm{I}^{(8)}$. This hormone increases the development of small antral follicles at the gonadotropin-dependent stages and stimulates oocyte maturation, while IGF increases proliferation of GC, steroidogenesis and oocyte growth in the majority of mammal species ${ }^{(27)}$. Thus, this condition could justify the maintenance of PAOF normality when cultured in medium containing $\mathrm{rbST}$, as verified in the present experiment.

In relation to the role of $\mathrm{T}_{4}$, some authors reported beneficial effects in animal folliculogenesis ${ }^{(10)}$ and in the culture of PAOF of goats ${ }^{(14)}$. Serakides et al. ${ }^{(28)}$ verified that rats treated with free $\mathrm{T}_{4}$ showed maintenance of follicular viability. Thyroid hormones have beneficial effects on the differentiation of follicular cells ${ }^{(28,29)}$. Furthermore, Serakides et al. ${ }^{(28)}$ observed a positive and significant correlation between primary follicles and $\mathrm{T}_{4}$ plasma concentrations, indicating that there is the participation of thyroid hormones on the development of primordial follicles, with consequent formation of primary follicles. However, the contribution of this hormone for follicular survival was not evidenced in the present study. According to Dijkstra et al. ${ }^{(29)}$ and Jiang et al. ${ }^{(30)}$, low $\mathrm{T}_{4}$ concentration can negatively affect folliculogenesis, leading to a greater number of atretic follicles. On the other hand, this condition had no influence on the present experiment, since the medium in the absence of $\mathrm{T}_{4}$, that is, only the base medium, also did not maintain the percentage of normal follicles during in vitro culture compared to the non-cultured control.

Regarding oocyte diameter, a reduction in the average diameter when PAOF were cultured in medium without the addition of $\mathrm{rbST}$ and $\mathrm{T}_{4}$ was verified (Table 2). However, this diameter was maintained after the cultures in medium containing these hormones, in isolated or associated manner. The 
follicular diameter is indicative of the normal development of the follicles, represented by the increase of the antral cavity and the multiplication of the granulosa cells around the oocyte.

There was no influence $(\mathrm{P}>0.01)$ of the medium used, regarding follicular diameter, when PAOF were cultured for seven days. These results are in contrast with those found by Kikuchi et al. ${ }^{(31)}$, who observed an increase in follicular diameter after four days of PAOF culture in media with higher concentrations of GH. According to Arunakumari et al. ${ }^{(32)}$, there is a synergism between $\mathrm{T}_{4}, \mathrm{FSH}_{\text {, }}$ IGF-I, and GH, which increases the rates of growth, antrum formation, and diameter increase, mainly when these are cultured for a longer period.

Table 2. Mean diameter (micrometers) of oocytes and preantral ovarian follicles noncultured and cultured for seven days, in medium without hormone $\left(\alpha-\mathrm{MEM}^{+}\right)$and with $\mathrm{rbST}$ or $\mathrm{T}_{4}$ (concentration in $\mathrm{ng} / \mathrm{mL}$ )

\begin{tabular}{lcc}
\hline Treatment & Oocyte diameter & Follicular diameter \\
\hline Control & $25.20 \pm 4.28^{\mathrm{a}}$ & $37.2 \pm 8.1$ \\
$\alpha-\mathrm{MEM}^{+}$ & $20.51 \pm 4.91^{\mathrm{b}}$ & $41.0 \pm 13.8$ \\
$\alpha-\mathrm{MEM}^{+}+\operatorname{rbST}(1,000)$ & $24.72 \pm 4.46^{\mathrm{a}}$ & $39.9 \pm 5.6$ \\
$\alpha-\mathrm{MEM}^{+}+\mathrm{T}_{4}(20)$ & $25.39 \pm 7.74^{\mathrm{a}}$ & $52.6 \pm 23.0$ \\
$\alpha-\mathrm{MEM}^{+}+\operatorname{rbST}(1,000)+\mathrm{T}_{4}(20)$ & $32.13 \pm 8.40^{\mathrm{a}}$ & $78.6 \pm 30.7$ \\
\hline
\end{tabular}

Different superscript letters represent a significant difference $(\mathrm{P}<0.05)$ by Kruskal-Wallis test.

For each treatment, 30 follicles were counted.

Although the average follicular diameter of PAOF cultured in medium containing rbST associated with $\mathrm{T}_{4}$ were numerically very high (78.6 micrometers), no difference $(\mathrm{P}>0.05)$ was observed when compared to the non-cultured control (37.2 micrometers). This discrepancy in the average occurred because a reading in the slides showed a PAOF with an excessively high diameter when compared to the readings of the others. No report of this accentuated discrepancy was found in the consulted literature, as well as an explanation for this fact observed. Thus, no homoscedasticity (one of the assumptions for parametric analysis, that is, ANOVA) occurred, even after the appropriate changes. The Kruskal-Wallis non-parametric test was then applied, which did not accuse difference $(\mathrm{P}>0.05)$ with the control, considering this discrepancy observed in one reading, which increased substantially the average diameter. In face of these considerations, it is prudent and correct to assume that there is no difference (as shown by the analysis), and this diameter observed in one PAOF was an isolated event and without the effect of treatment. A similar situation, although of lower intensity, was verified in one PAOF cultured in medium containing $\mathrm{T}_{4}$.

Ultrastructural analysis was performed in PAOF cultured for seven days (Figure 2). This evaluation was performed since some conditions presented by the follicles can only be observed at ultrastructure level, as the presence of cytoplasmic organelles, the condition of GC, the quantity of cytoplasmic vacuoles, and the integrity of cell membranes after in vitro culture ${ }^{(33)}$.

The absence of cytoplasmic organelles, such as mitochondria, endoplasmic reticulum, irregular cariotheca, and a lot of vacuoles in the cytoplasm, was observed, being an indication of degeneration (Figure 2), as also reported by Faustino et al. ${ }^{(34)}$.

Therefore, although media containing rbST or this hormone associated with $\mathrm{T}_{4}$ have maintained follicular survival, observed by optical microscopy (Table 1), follicular survival was not confirmed after transmission electron microscopy, on which degenerative alterations were observed, showing 
the necessity of improvements in the composition of media for in situ culture of bovine PAOF.

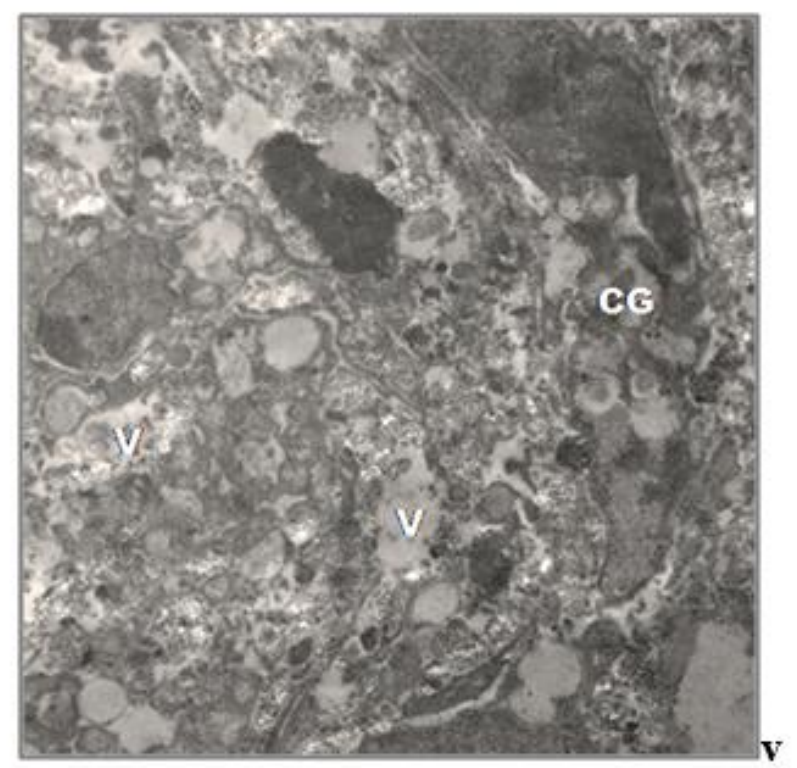

Figure 2. Ultrastructure of bovine preantral follicle cultured for seven days in medium containing $1,000 \mathrm{ng} / \mathrm{mL} \mathrm{rbST}$ and $20 \mathrm{ng} / \mathrm{mL} \mathrm{T}_{4}$. The absence of organelles is observed. GC: granulosa cells, V: vacuoles. 3,000x magnification

\section{Conclusions}

Although the presence of rbST in culture medium of bovine preantral follicles maintained the rate of morphologically normal follicles during the culture for seven days (observed by optical microscopy), the use of rbST and $\mathrm{T}_{4}$ in in situ culture medium of bovine PAOF, at the concentrations used in the present experiment, does not exert beneficial effects on its ultrastructural integrity and oocyte and follicular growth.

\section{Acknowledgments}

We gratefully acknowledge to FAPEMIG for the financial support; CAPES for providing the postgraduation scholarship. The Nucleus of Microscopy and Microanalysis of the Federal University of Viçosa (UFV) for the support in the processing and ultrastructural analysis.

\section{References}

1. Liu J, Van Der Elst J, Van Den Broeck R, Dhont M. Live offspring by in vitro oocytes from cryopreserved primordial mouse follicles after sequential in vivo transplantation and in vitro maturation. Biology of Reproduction.2001; 64:171-178.

2. Mao J, Wu G, Smith MF, Mccauley TC, Cantley TC, Prather RS, Didion BA, Day BN. Effects of 
culturemedium, serumtype, and various concentrations of follicle-stimulating hormone on porcine preantral follicular development and antrum formation in vitro. Biology Reproduction.2002; 67:197-203.

3. Figueiredo JR, Rodrigues APR, Amorim CA, Silva JRV. Manipulação de OócitosInclusosemFolículosOvarianosPré-Antrais - MOIFOPA. In: Gonçalves, P.B.D; Figueiredo, J.R.; Freitas, V.J.F. (2 ed). BiotécnicasAplicadas à Reprodução Animal. São Paulo: Rocca. 2008; 303-327.

4.Fouladi-Nashta AA, Campbell KHS. Dissociation of oocyte nuclear and cytoplasmic maturation by the addition of insulin in cultured bovine antral follicles. Reproduction.2006; 131:449-460.

5. Figueiredo JR, Hulshof SCJ, Van Den Hurk R, Nusgens B, Bevers MM, Ectors FJ, Beckers JF. Preservation of oocyte and granulosa cell morphology in bovine preantral follicles cultured in vitro. Theriogenology.1994; 41:1333-1346.

6. Itoh T, Kacchi M, Abe H, Sendai Y, Hoshi H. Growth, antrum formation, and estradiol production of bovine preantral follicles cultured in a serum-free medium. Biology Reproduction. 2002; 67:1099-1105.

7. Mclaughlin M, Bromfield JJ, Albertini DF, Telfer EE. Activin promotes follicular integrity and oogenesis in cultured pre-antral bovine follicles. Molecular Human Reproduction. 2010; 16:644-653.

8. Iga K, Niwa K, Bartke A. Recombinant bovine growth hormone stimulates nuclear maturation of bovine oocytes in vitro and promotes subsequent embryonic development. Journal of Reproduction and Development.1998; 44:45-52.

9. Ferreira AT, Souza JC, Pereira MN, Pérez JRO, Rocha GP. Influência da Somatotropina Bovina Recombinante (rbST), aplicada um diaapós o parto, sobre a produção de vacas da raçaHolandêsprimíparas.Ciência e Agrotecnologia, Edição Especial. 2002; 1568-1574.

10. Arunakumari G, Vagdevi R, Rao BS, Naik BR, Naidu KS, Suresh Kumar RV, Rao VH. Effect of hormones and growth factors on in vitrodevelopment of sheep preantral follicles. Small Ruminant Research. 2007; 70:93100 .

11. Dickson WM. Endocrinology. In: Swenson, M.J., Reece, W.O. (eds) Reproduction and Lactation. Ducke's Physiology of Domestic Animals. Panima Publishing Corporation, New Delhi. 1996; 629-710.

12. Chaves RN, Martins FS, Saraiva MVA, Celestino JJH, Lopes CAP, Correia JC, Verde IB, Matos MH, Báo SN, Name KP, Campello CC, Silva JR, Figueiredo JR. Chilling ovarian fragments during transportation improves viability and growth of goat preantral follicles cultured in vitro. Reproduction, Fertility and Development.2008; 20:640-647.

13. Silva, T.F. Efeito da SomatotropinaRecombinante Bovina (rbST) no desenvolvimentoin vitro de folículospré-antrais de bovinos. 2014. 50f. Dissertação (Mestrado) - Departamento de Veterinária Universidade Federal de Viçosa, Viçosa, 2014.

14. Costa SL, Costa EP, Pereira ECM, Gonçalves WG, Silva TF, Queiroz VLD. Association between insulinlike growth factor-I, thyroxineand follicle stimulating hormone on the survival and in vitrodevelopment of caprinepreantral follicles. Revista Brasileira Ciência Veterinária. 2014; 21:110-116.

15. Bruno JB, Lima-Verde IB, Martins FS, Matos MHT, Lopes CAP, Maia-Jr JE, Báo SN, Nobre Junior HV, Maia FD, Pessoa C, Moraes MO, Silva JRV, Figueiredo JR, Rodrigues APR. Característicahistológica, ultraestrutural e produção de nitrito de folículospré-antraiscaprinoscultivadosin vitronaausênciaoupresença de soro. ArquivoBrasileiro de MedicinaVeterinária e Zootecnia.2008; 60:1329-1337.

16. Silva JRV, Ferreira MAL, Costa SHF, Santos RR, Carvalho FCA, Rodrigues APR, Lucci CM, Báo SN, Figueiredo JR. Degeneration rate of pré-antral follicles in the ovaries of goats. Small Ruminant Research.2002; 43:203-209.

17. Costa E.P. Aspectosmorfológicos (citológicos e ultraestruturais) e desenvolvimento de ovócitos de bovinos "in vitro". 1994. 155f. Tese (Doutorado) - Escola de Veterinária- Universidade Federal de Minas Gerais, Belo Horizonte, 1994. 
18. Basso AC, Esper CR. Isolamento e caracterizaçãoultraestrutural de folículospré-antrais de vacas da raçaNelore (Bostaurusindicus). Brazilian Journal of Veterinary Researchand Animal Science.2002; 39:311319.

19. Watson M.L. Staining of tissue sections for electron microscopy with heavy metals. Journal of Biophysics and Biochemistry Citology.1958; 4:475.

20. Reynolds ES. The use of the lead citrate at high $\mathrm{pH}$ as an electron-opaque stain in electron microscopy. Journal of Cell Biology 1963; 17:208.

21. Sistema de análiseestatística e genética (SAEG), UFV, Central de processamento de dados, Viçosa- M.G. 1999.

22. Silva CM, Serakides R, Oliveira T, Ocarino NM, Nascimento EF, Nunes VA. Histomorfometria e histoquímica dos ovários, tubas e útero de ratashipotireóideasemmetaestro-diestro. Arquivo Brasileiro de MedicinaVeterinária e Zootecnia. 2004a; 56:628-639.

23. Liu HC, He Z, Rosenwaks Z. In vitro culture and in vitro maturation of mouse preantral follicles with recombinant gonadotropins. Fertility and Sterility.2002; 77:373-383.

24. Demeestere I, Gervy C, Centner J, Devreker F, Englert Y, Delbaere A. Effect of insulin-like growth factorI during preantral follicular culture on steroidogenesis, in vitro oocyte maturation, and embryo development in mice. Biology of Reproduction.2004; 70:1664-1669.

25. BuratiniJr J, Price CA, Visintin JA. Effects of dominant follicle aspiration and treatment with recombinant bovine somatotropin (bST) on ovarian follicular development in Nelore (Bosindicus) heifers. Theriogenolgy. 2000; 54:421-431.

26. Chun SY, Billi H, Furuta I, Tsafriri A, Hsueh AJ. Gonadotropin supression of apoptose in cultured preovulatoryfollilces: mediatory roles of endogenous insulin-like growth factor I. Endocrinology. 1994; 135:1845-1853.

27. Silva JRV, Figueiredo JR, Van Den Hurk R. Involvement of growth hormone (GH) and insulin-like growth factor (IGF) system in ovarian folliculogenesis. Theriogenology.2009; 71:1193-1208.

28. Serakides R, Nunes VA, Nascimento E, Ribeiro AFC, Silva CM. Foliculogênese e esteroidogênese ovarianas em ratas adultas hipertireóideas. Arquivos Brasileiros de Endocrinologia \& Metabologia. 2001; 45:258-264.

29. Dijkstra G, Rooij DG, Jong FH, Van Der Hurk R. Effect of hypothyroidism on ovarian follicular development, granulosa cell proliferation and peripheral hormone levels in the prepubertal rat. European Journal of Endocrinology. 1996; 134:649-654.

30. Jiang JY, Umezu M, Sato E. Improvement of follicular development rather than gonadotrophin secretion by thyroxine treatment in infertile immature hypothyroid $r d w$ rats. Journal of Reproduction and Fertility. 2000; 119:193-199.

31. Kikuchi N, Andoh K, Abe Y, Yamada K, Mizunuma H, Ibuki Y. Inhibitory action of leptin on early follicular growth differs in immature and adult female mice. Biology Reproduction.2001; 65:66-71.

32. Arunakumari G, Shanmugasundaram N, Rao VH. Development of morula e from the oocytes of cultured sheep preantral follicles. Theriogenology. 2010; 74:884-894.

33. Araújo VCR, Silva CMG, Magalhães DM, Silva GM, Báo SN, Silva JRV, Figueiredo JR, Rodrigues APR. Effect of Bone Morphogenetic Protein-7 (BMP-7) on in vitro survival of caprinepreantral follicles. Pesquisa Veterinária Brasileira. 2010; 30:305-310.

34. Faustino LR, Lima IMT, Carvalho AA, Silva CMG, Castro SV, Lobo CH, Lucci CM, Campello CC, Figueiredo JR, Rodrigues APR. Interaction between keratinocyte growh fator-1 and kit ligand on the goat preanttal follicles cultured in vitro. Small Ruminant Research.2013; 114:112-119. 